\title{
Normative data for middle-aged Brazilians in the Mattis Dementia Rating Scale
}

\author{
Guilherme Almeida Carvalho ${ }^{1,2} \odot$, Paulo Caramelliं,3 $\odot$
}

\begin{abstract}
Despite the advances in the diagnosis of dementia, neuropsychological assessment remains an important tool. The Mattis Dementia Rating Scale (DRS) was designed to evaluate people with suspected dementia and allows for the analysis of different cognitive domains. Considering the numerous cases of early-onset dementia, specific reference standards aimed at the middle-aged population are necessary. Objective: To provide normative data for the middle-aged Brazilian population in DRS and to investigate the influence of education level, age, sex, and intelligence quotient (IQ) on the results. Methods: Overall, 120 healthcare professionals and caregivers from a hospital, who were healthy, aged between 45 and 64 years, and had at least four years of formal education, were included in the study. They were equally divided into six groups. In each age group (45-54 and 55-64 years), there were three educational levels: $4-7,8-11$, and 12 or more $(12+)$ years of formal education. The results are presented as mean values, standard deviations, and percentiles. Comparisons between groups were carried out for age, sex, and education level. Age, years of formal education, and IQ were also analyzed as continuous variables by Spearman's correlation. Results: Concerning education level, the comparison between groups showed differences in the results for the total scale and subscales, except for the Construction subscale. No differences were found for age and sex. Correlations observed for years of formal education and IQ were similar. No correlation was found for age. Conclusions: The present study contributes to the evaluation of dementia concerning people younger than 65 years of age and reinforces the importance of education in the interpretation of the scores.
\end{abstract}

Keywords: mental status and dementia tests, education, Brazil, reference standards, middle aged.

\section{DADOS NORMATIVOS PARA BRASILEIROS DE MEIA-IDADE NA ESCALA DE AVALIAÇ̃̃O DE DEMÊNCIA DE MATTIS}

RESUMO. Apesar dos avanços no diagnóstico de demência, a avaliação neuropsicológica continua sendo uma importante ferramenta. A Escala de Avaliação de Demência de Mattis (Mattis Dementia Rating Scale — DRS) foi projetada para avaliar pessoas com suspeita de demência e permite a análise de diferentes domínios cognitivos. Dados os numerosos casos de demência com início precoce, são necessárias normas específicas para a população de meia-idade. Objetivo: Fornecer dados normativos para a população brasileira de meia-idade na escala Mattis e investigar a influência da escolaridade, idade, sexo e quociente de inteligência (Ql) nos resultados. Métodos: 120 funcionários e cuidadores saudáveis de um hospital, com idade entre 45 e 64 anos e com pelo menos quatro anos de escolaridade foram incluídos no estudo, os quais foram divididos igualmente em seis grupos. Havia três níveis educacionais para cada faixa etária (45-54 e 55-64 anos): 4 a 7 anos de estudo (4-7), 8 a 11 (8-11) e 12 anos ou mais (12+). 0s resultados são apresentados como valores médios, desvios padrão e percentis. Foram realizadas comparações entre os grupos de acordo com idade, sexo e escolaridade. Idade, anos de estudo e Ql foram também analisados como variáveis contínuas através da correlação de Spearman. Resultados: Para a educação, a comparação entre os grupos mostrou diferenças nos resultados da escala total e subescalas, exceto na subescala Construção. Não foram identificadas diferenças para idade e sexo. As correlações observadas para anos de estudo e Ql foram semelhantes. Nenhuma correlação foi encontrada para idade. Conclusão: 0 presente estudo contribui para a avaliação da demência em indivíduos com menos de 65 anos e reforça a importância de considerar o nível educacional na interpretação dos escores.

Palavras-chave: testes de estado mental e demência, educação, Brasil, padrões de referência, pessoas de meia-idade.

\footnotetext{
This study was conducted at the Faculdade de Medicina, Universidade Federal de Minas Gerais, Belo Horizonte, MG, Brazil.

'Rede Sarah de Hospitais de Reabilitação - Belo Horizonte, MG, Brazil. ${ }^{2}$ Programa de Pós-Graduação em Ciências Aplicadas à Saúde do Adulto, Faculdade de Medicina, Universidade Federal de Minas Gerais - Belo Horizonte, MG, Brazil. ${ }^{3}$ Grupo de Pesquisa em Neurologia Cognitiva e do Comportamento, Departamento de Clínica Médica, Faculdade de Medicina, Universidade Federal de Minas Gerais - Belo Horizonte, MG, Brazil.
}

Guilherme Almeida Carvalho. Rede Sarah de Hospitais de Reabilitação - Avenida Amazonas, 5953 - Gameleira - 30510-000 Belo Horizonte MG - Brazil. E-mail: guilhermegoog@gmail.com

Disclosure: The authors report no conflicts of interest.

Funding: none.

Received on June 24, 2019. Accepted in final form on September 17, 2020.

\section{(c) BY}




\section{INTRODUCTION}

$\mathrm{D}$ espite the many advances in the diagnosis of dementia, neuropsychological assessment remains an essential tool in this process. ${ }^{1}$ Some of the most popular neuropsychological test batteries used to detect dementia, such as the Mini-Mental State Examination (MMSE) and the Mini-Cog, are brief. ${ }^{2}$ They are useful for dementia screening, but have limitations in the adequate characterization of neuropsychological profiles and dementia staging.

Conversely, a comprehensive neuropsychological assessment requires many sessions, and some tasks can be difficult for moderate or severe stages of cognitive impairment. The Mattis Dementia Rating Scale (DRS) is a neuropsychological test battery designed for people with known or suspected dementia. ${ }^{3}$ The tasks are suitable for people in different dementia stages, allowing for the analysis of specific cognitive domains and the follow-up of cognitive functioning over time. The evaluation of patients with dementia carried out with DRS usually lasts 30 to 45 minutes.

The total scale is divided into five subscales: Attention (ATT), Initiation/Perseveration (I/P), Construction (CONST), Conceptualization (CONCEPT), and Memory (MEM). This division enables the identification of different cognitive profiles in distinct forms of dementia, thus contributing to a differential diagnosis. When different dementing disorders were compared, studies showed comparable total scores, but differences on subscales. Patients with Alzheimer's disease (AD) score worse on the MEM subscale than patients with other disorders such as frontotemporal dementia, ${ }^{4}$ vascular dementia, ${ }^{5}$ Huntington's disease, or progressive supranuclear palsy. ${ }^{6}$ On the other hand, patients with AD had better performance on I/P.

In Brazil, Porto et al. ${ }^{7,8}$ and Foss et al..$^{9,10}$ conducted studies to adapt the scale and define standards for the Brazilian population. These studies confirm international findings regarding the influence of age and education on the results. Strauss et al. recommend that normative data be classified according to age and education level. ${ }^{3}$

Most cases of dementia begin after the age of $65 .{ }^{11}$ However, some cases present an early onset, indicating that normative data for this population are necessary. In a population-based study aiming to investigate the prevalence of dementia in a small Brazilian city, César found a prevalence of $5.3 \%$ among individuals aged 60 to 64 years, which is five times higher than in other regions worldwide. The author stated that this finding is probably related to low educational levels. ${ }^{12}$

In the normative study conducted by Foss et al. on 502 Brazilians, there were fewer participants under the age of 60 . Thus, the authors recommended additional studies with more participants in the age group of 50-60 years. ${ }^{10}$

The present study aimed to provide normative data for individuals aged 45 to 64 years and to investigate the influence of education level, age, sex, and intelligence quotient (IQ) on results of the DRS.

\section{METHODS}

A more detailed description of the methods can be found on a previous study. ${ }^{13}$

\section{Participants}

The sample consisted of 120 healthcare professionals and caregivers from a hospital, who were cognitively-healthy, aged between 45 and 64 years, had at least four years of formal education, and were randomly selected. They were equally divided into six groups according to age and education level. In each age group (45-54 and 55-64 years), there were three education levels: 4-7, 8-11, and 12 or more (12+) years of formal education.

Individuals with neurological and psychiatric disorders whose symptoms could cause cognitive impairment at the time of the tests were excluded as well as subjects with hearing or visual impairment. Moreover, individuals who reported the use of psychoactive drugs within three weeks prior to the administration of the tests were excluded. Subjects who reported alcohol dependence or who were using illicit drugs were also excluded.

\section{Setting}

The study was approved by the Ethics Committees of Hospital Sarah and Universidade Federal de Minas Gerais. The first author, who has considerable experience with neuropsychological examination, collected data in an appropriate room at Hospital Sarah in Belo Horizonte (state of Minas Gerais), Brazil, between May 2015 and October 2016.

\section{Instruments}

The MMSE was used as a study entry criterion. Individuals below the established education-adjusted cutoff points were excluded (24 for 4-7 years of formal education, and 26 for 8 or more years). ${ }^{14,15}$ Modules A, J, and O of the Mini-International Neuropsychiatric Interview (MINI) were also performed to investigate frequent psychiatric disorders. ${ }^{16,17}$ Individuals who met the criteria for major depressive disorder, generalized anxiety disorder, or alcohol dependence, according to MINI, were excluded from the study. Participants also completed the 
two-subtest form of the Wechsler Abbreviated Scale of Intelligence (WASI) to determine their IQ. ${ }^{18}$

DRS has a total score of 144 , which is divided among the five subscales, namely: 37 points related to the ATT subscale; 37 , to I/P; six, to CONST; 39, to CONCEPT; and 25, to MEM. ${ }^{7}$ Table 1 shows a brief description of the subtests in the subscales. ${ }^{3,7}$

\section{Procedures}

In the first session, after signing the informed consent form, the participants attended an interview and

Table 1. Brief description of the Mattis Dementia Rating Scale subtests.

\begin{tabular}{|c|c|c|}
\hline Subscale & Subtests & $\begin{array}{l}\text { Maximum } \\
\text { points }\end{array}$ \\
\hline \multirow{6}{*}{ Attention } & Digit span & \multirow{6}{*}{37} \\
\hline & Commands & \\
\hline & Imitation & \\
\hline & Letter A counting (two tasks) & \\
\hline & Word list reading & \\
\hline & Visual matching & \\
\hline \multirow{4}{*}{$\begin{array}{l}\text { Initiation/ } \\
\text { Perseveration }\end{array}$} & $\begin{array}{l}\text { Verbal fluency tests (supermarket } \\
\text { products and body parts) }\end{array}$ & \multirow{4}{*}{37} \\
\hline & Sound repetition & \\
\hline & Alternating movements & \\
\hline & Graphomotor design & \\
\hline Construction & Copying designs & 6 \\
\hline \multirow{4}{*}{ Conceptualization } & Similarities & \multirow{4}{*}{39} \\
\hline & Inductive reasoning & \\
\hline & Differences & \\
\hline & Similarities - Multiple choice & \\
\hline \multirow{4}{*}{ Memory } & Orientation & \multirow{4}{*}{25} \\
\hline & $\begin{array}{l}\text { Verbal recall - reading and sentence } \\
\text { generated by the examinee }\end{array}$ & \\
\hline & $\begin{array}{l}\text { Verbal recognition (word list reading } \\
\text { from the Attention subscale) }\end{array}$ & \\
\hline & $\begin{array}{l}\text { Visual recognition (visual matching } \\
\text { from the Attention subscale) }\end{array}$ & \\
\hline
\end{tabular}

Total score

Sources: Scoring Booklet ${ }^{\star}$ and Strauss et al. ${ }^{3}$

*The scoring booklet of the Brazilian adaptation was kindly

provided by the Department of Neurology - Hospital das Clínicas

da Faculdade de Medicina da Universidade de São Paulo. ${ }^{7}$ completed the MMSE and the MINI. In a second session, the application of the WASI and DRS was carried out.

In the interview, age, years of formal education, history of possible neurological and psychiatric illnesses, health conditions, medications in use, and possible history of consumption of alcoholic beverages and drug use were verified.

\section{Statistical analysis}

The Shapiro-Wilk test was used to verify the hypothesis of normal distribution. Nonparametric tests were the most appropriate for the analyses.

The Kruskal-Wallis test (K-W) was chosen to compare the groups according to education level, and the Mann-Whitney (M-W) test was used for post hoc analyses with a Bonferroni correction for $\mathrm{p}$-values. The Mann-Whitney test was used in paired comparisons to analyze sex and age. Age, years of formal education, and IQ were also analyzed as continuous variables with Spearman's correlation $\left(r_{s}\right)$. The classification suggested by Siqueira and Tibúrcio was followed to interpret the correlations: $0-0.4$, weak; $0.4-0.7$, moderate; and $0.7-1.0$, strong. ${ }^{19}$

All analyses were performed using the Statistical Package for the Social Sciences (SPSS) software, version 20.0. The considered level of significance was $\mathrm{p}<0.05$. In cases in which the Bonferroni correction was performed, $\mathrm{p}<0.017$ was considered significant.

\section{RESULTS}

Overall, 153 individuals were invited to participate in the study. There were 13 nonrespondents and 18 exclusions: 12 due to the use of medications with potential negative cognitive effects; one due to neurological disease; one for being outside the age group; and four for failing to meet the diagnostic criteria of the MINI interview. Of the 122 participants included, two withdrew during the second stage, in which the WASI and DRS were applied.

Table 2 shows the sociodemographic characteristics of the participants. Results of DRS are presented as mean values, standard deviations, and percentiles (Table 3). Considering the non-normal frequency distribution, the use of percentiles $(\mathrm{P})$ was recommended.

\section{Education level}

Analyses between groups showed significant differences for total and subscale scores $(\mathrm{p}<0.001)$, except for the CONST subscale (Table 4).

Post hoc analyses showed a difference in paired comparisons among the three education levels on total 
Table 2. Sociodemographic characteristics of the participants.

\begin{tabular}{lccccc}
\hline Groups (years of formal education/age) & Age (years) $^{\mathrm{a}}$ & Years of formal education $^{1}$ & Sex $^{\mathrm{b}}$ & IQ $^{\mathrm{a}}$ & $\mathbf{n}$ \\
\hline $4-7 / 45-64$ & $49.9 \pm 3.1$ & $5.2 \pm 1.1$ & $10(50 \%)$ & $81.4 \pm 14.2$ & $20(16.7 \%)$ \\
\hline $4-7 / 55-64$ & $59.3 \pm 2.9$ & $5.0 \pm 1.4$ & $13(65 \%)$ & $77.2 \pm 9.5$ & $20(16.7 \%)$ \\
\hline $8-11 / 45-64$ & $49.7 \pm 2.5$ & $10.7 \pm 0.8$ & $11(55 \%)$ & $96.5 \pm 11.2$ & $20(16.7 \%)$ \\
\hline $8-11 / 55-64$ & $57.9 \pm 1.8$ & $10.1 \pm 1.3$ & $15(75 \%)$ & $91.9 \pm 16.5$ & $20(16.7 \%)$ \\
\hline$\geq 12 / 45-64$ & $48.8 \pm 2.8$ & $15.6 \pm 2.4$ & $15(75 \%)$ & $110.9 \pm 11.1$ & $20(16.7 \%)$ \\
\hline$\geq 12 / 55-64$ & $58.5 \pm 2.3$ & $16.9 \pm 2.7$ & $15(75 \%)$ & $111.3 \pm 10.5$ & $20(16.7 \%)$ \\
\hline
\end{tabular}

Source: Prepared by the authors.

${ }^{a}$ Mean values \pm standard deviation; ${ }^{b}$ percentage of females; IQ: intelligence quotient.

Table 3. Normative data in the Mattis Dementia Rating Scale.

\begin{tabular}{|c|c|c|c|c|c|c|}
\hline \multirow{2}{*}{$\frac{\text { Age (years) }}{\text { Education level (years) }}$} & \multicolumn{3}{|c|}{45 to 54} & \multicolumn{3}{|c|}{55 to 64} \\
\hline & $4-7$ & $8-11$ & $12+$ & $4-7$ & $8-11$ & $12+$ \\
\hline \multicolumn{7}{|l|}{ Total score } \\
\hline Mean values $\pm S D$ & $128.7 \pm 7.6$ & $135.9 \pm 4.8$ & $138.9 \pm 3.2$ & $128.6 \pm 5.6$ & $132.2 \pm 5.2$ & $139.2 \pm 3.4$ \\
\hline P90 & 139 & 141 & 143 & 136 & 140 & 143 \\
\hline P75 & 134 & 139 & 141 & 134 & 138 & 142 \\
\hline Median & 130 & 137 & 140 & 128 & 131 & 140 \\
\hline P25 & 126 & 134 & 136 & 124 & 128 & 133 \\
\hline P10 & 114 & 127 & 134 & 121 & 126 & 133 \\
\hline \multicolumn{7}{|l|}{ Attention } \\
\hline Mean values $\pm S D$ & $35.9 \pm 1.0$ & $36.2 \pm 1.3$ & $36.5 \pm 0.7$ & $35.5 \pm 1.0$ & $35.7 \pm 1.3$ & $36.7 \pm 0.6$ \\
\hline P90 & 37 & 37 & 37 & 37 & 37 & 37 \\
\hline P75 & 37 & 37 & 37 & 36 & 37 & 37 \\
\hline Median & 36 & 37 & 37 & 36 & 36 & 37 \\
\hline P25 & 35 & 35 & 36 & 35 & 35 & 36 \\
\hline P10 & 34 & 34 & 35 & 34 & 33 & 36 \\
\hline \multicolumn{7}{|l|}{ Initiation/Perseveration } \\
\hline Mean values \pm SD & $32.8 \pm 4.1$ & $35.9 \pm 1.8$ & $36.7 \pm 0.7$ & $34.5 \pm 2.1$ & $34.7 \pm 3.1$ & $36.2 \pm 1.6$ \\
\hline P90 & 37 & 37 & 37 & 37 & 37 & 37 \\
\hline P75 & 37 & 37 & 37 & 36 & 37 & 37 \\
\hline Median & 33 & 37 & 37 & 35 & 36 & 37 \\
\hline P25 & 31 & 36 & 36 & 33 & 32 & 36 \\
\hline P10 & 26 & 32 & 35 & 31 & 31 & 33 \\
\hline
\end{tabular}


Table 3. Continuation.

\begin{tabular}{|c|c|c|c|c|c|c|}
\hline \multirow{2}{*}{$\begin{array}{l}\text { Age (years) } \\
\text { Education level (years) }\end{array}$} & \multicolumn{3}{|c|}{45 to 54} & \multicolumn{3}{|c|}{55 to 64} \\
\hline & 4-7 & $8-11$ & $12+$ & $4-7$ & 8-11 & $12+$ \\
\hline \multicolumn{7}{|l|}{ Construction } \\
\hline Mean values \pm SD & $5.7 \pm 1.1$ & $6.0 \pm 0.2$ & $6.0 \pm 0.0$ & $5.5 \pm 1.1$ & $6.0 \pm 0.2$ & $6.0 \pm 0.0$ \\
\hline P90 & 6 & 6 & 6 & 6 & 6 & 6 \\
\hline P75 & 6 & 6 & 6 & 6 & 6 & 6 \\
\hline Median & 6 & 6 & 6 & 6 & 6 & 6 \\
\hline P25 & 6 & 6 & 6 & 6 & 6 & 6 \\
\hline P10 & 3 & 6 & 6 & 3 & 6 & 6 \\
\hline \multicolumn{7}{|l|}{ Conceptualization } \\
\hline Mean values $\pm S D$ & $31.1 \pm 4.1$ & $34.7 \pm 2.9$ & $35.6 \pm 2.2$ & $29.8 \pm 5.0$ & $32.8 \pm 4.2$ & $36.2 \pm 2.7$ \\
\hline P90 & 37 & 38 & 38 & 37 & 38 & 39 \\
\hline P75 & 34 & 37 & 37 & 33 & 37 & 38 \\
\hline Median & 31 & 36 & 36 & 31 & 34 & 37 \\
\hline P25 & 28 & 33 & 34 & 26 & 29 & 35 \\
\hline P10 & 26 & 29 & 31 & 23 & 27 & 31 \\
\hline \multicolumn{7}{|l|}{ Memory } \\
\hline Mean values $\pm S D$ & $23.3 \pm 1.4$ & $23.2 \pm 1.5$ & $24.2 \pm 1.1$ & $23.4 \pm 1.3$ & $23.1 \pm 1.5$ & $24.3 \pm 1.0$ \\
\hline P90 & 25 & 25 & 25 & 25 & 25 & 25 \\
\hline P75 & 24 & 24 & 25 & 24 & 24 & 25 \\
\hline Median & 24 & 24 & 25 & 23 & 23 & 25 \\
\hline P25 & 22 & 23 & 23 & 23 & 22 & 24 \\
\hline P10 & 21 & 22 & 22 & 21 & 21 & 22 \\
\hline
\end{tabular}

Source: prepared by the authors.

SD: standard deviation; $P$ : percentile; $n=20$ for each group.

Table 4. Comparisons between groups according to education level in the Mattis Dementia Rating Scale.

\begin{tabular}{|c|c|c|c|c|}
\hline Education level (years) & $4-7$ & 8-11 & $\geq 12$ & \\
\hline Results & $\begin{array}{c}\text { Mean value } \pm \text { SD } \\
\text { Median } \\
(Q 1 ; Q 3)\end{array}$ & $\begin{array}{c}\text { Mean value } \pm S D \\
\text { Median } \\
(Q 1 ; Q 3)\end{array}$ & $\begin{array}{c}\text { Mean value } \pm S D \\
\text { Median } \\
(Q 1 ; Q 3)\end{array}$ & $p$-value \\
\hline Total score & $\begin{array}{c}128.60 \pm 6.62 \\
128.5(125.25 ; 133.50)\end{array}$ & $\begin{array}{c}134.03 \pm 5.26 \\
135.50(129.00 ; 138.75)\end{array}$ & $\begin{array}{c}139.00 \pm 3.25 \\
140.00 \\
(137.00 ; 141.00)\end{array}$ & $<0.001$ \\
\hline Attention & $\begin{array}{c}35.68 \pm 1.00 \\
36.00 \\
(35.00 ; 36.00)\end{array}$ & $\begin{array}{c}35.93 \pm 1.31 \\
36.00 \\
(35.00 ; 37.00)\end{array}$ & $\begin{array}{c}36.55 \pm 0.64 \\
37.00 \\
(36.00 ; 37.00)\end{array}$ & $<0.001$ \\
\hline
\end{tabular}


Table 4. Continuation.

\begin{tabular}{|c|c|c|c|c|}
\hline Education level (years) & $4-7$ & $8-11$ & $\geq 12$ & \\
\hline Initiation/perseveration & $\begin{array}{c}33.63 \pm 3.30 \\
34.50 \\
(31.25 ; 36.00)\end{array}$ & $\begin{array}{c}35.28 \pm 2.57 \\
36.50 \\
(34.00 ; 37.00)\end{array}$ & $\begin{array}{c}36.40 \pm 1.24 \\
37.00 \\
(36.00 ; 37.00)\end{array}$ & $<0.001$ \\
\hline Construction & $\begin{array}{c}5.58 \pm 1.06 \\
6.00 \\
(6.00 ; 6.00)\end{array}$ & $\begin{array}{c}5.95 \pm 0.22 \\
6.00 \\
(6.00 ; 6.00)\end{array}$ & - & - \\
\hline Conceptualization & $\begin{array}{c}30.43 \pm 4.56 \\
31.00 \\
(27.00 ; 34.00)\end{array}$ & $\begin{array}{c}33.73 \pm 3.71 \\
35.00 \\
(31.25 ; 37.00)\end{array}$ & $\begin{array}{c}35.85 \pm 2.49 \\
36.50 \\
(35.00 ; 37.75)\end{array}$ & $<0.001$ \\
\hline Memory & $\begin{array}{c}23.30 \pm 1.32 \\
24.00 \\
(23.00 ; 24.00)\end{array}$ & $\begin{array}{c}23.15 \pm 1.46 \\
23.00 \\
(23.00 ; 24.00)\end{array}$ & $\begin{array}{c}24.20 \pm 1.04 \\
25.00 \\
(23.25 ; 25.00)\end{array}$ & $<0.001$ \\
\hline
\end{tabular}

Source: prepared by the authors.

SD: standard deviation; $\mathrm{n}=40$ for each group.

Table 5. Spearman's correlation $\left(r_{s}\right)$ for years of formal education, intelligence quotient, and age.

\begin{tabular}{lcccccc}
\hline & $\begin{array}{c}\text { Years of formal } \\
\text { education }\end{array}$ & p-value & IQ & p-value & Age & p-value \\
\hline Total scale & 0.704 & $<0.001$ & 0.812 & $<0.001$ & -0.132 & $=0.151$ \\
\hline Attention & 0.373 & $<0.001$ & 0.492 & $<0.001$ & -0.130 & $=0.158$ \\
\hline Initiation/perseveration & 0.463 & $<0.001$ & 0.455 & $<0.001$ & -0.044 & $=0.635$ \\
\hline Construction & 0.243 & $=0.007$ & 0.287 & $=0.001$ & -0.067 & -0.105 \\
\hline Conceptualization & 0.604 & $<0.001$ & 0.730 & $<0.001$ & -0.469 & $=0.254$ \\
\hline Memory & 0.316 & $<0.001$ & 0.361 & $<0.001$ & -0.001 & $=0.988$ \\
\hline
\end{tabular}

Source: prepared by the authors.

IQ: intelligence quotient; $n=120$.

scores and the CONCEPT subscale. In the I/P group, differences were observed in the comparison of the 4-7 group with the $8-11$ and $12+$ groups. The MEM subscale evidenced differences between the 8-11 and $12+$ groups as well as between the 4-7 and $12+$ groups.

There were positive correlations between years of formal education and results for the total and subscale scores. Correlations were strong for the total score, moderate for the CONCEPT and I/P subscales, and weak for ATT, MEM, and CONST subscales (Table 5).

\section{Age, sex, and intelligence quotient}

Age and sex did not influence the performance on DRS in paired comparisons. Similarly, no correlations were verified between DRS results and these factors.

Conversely, IQ significantly influenced performance. Positive correlations were strong for the total score and the CONCEPT subscale, whereas correlations were moderate for the ATT and I/P subscales and weak for the CONST and MEM subscales.

\section{DISCUSSION}

The present study contributes to normative data for middle-aged Brazilians in the DRS. As discussed by Foss et al., ${ }^{10}$ studies on Brazilians within this age group are necessary. As aforementioned, the results of this study confirm the influence of education level on the performance on DRS. ${ }^{3,8-10,20,21}$ Regarding the subtests, this influence was stronger on the CONCEPT subscale and moderate on the I/P and ATT subscales.

In the CONCEPT subscale, there are essentially verbal and nonverbal tasks demanding analogies and classification. Such skills are often developed in school, 
justifying greater ability for people with higher education level. The I/P subscale is mainly composed of fluency tests. The education level also contributes to greater storage of semantic memory. ${ }^{22}$

Smith et al. ${ }^{23}$ concluded that the CONCEPT and MEM subscales, as well as the total score on DRS, display good psychometric properties. On the other hand, these authors stated that the ATT and CONST subscales should be carefully used, whereas reliability was not found for I/P. The lower influence of education on the MEM subtest in the present study reinforces its usefulness for diagnostic purposes. Lukatela et al. ${ }^{5}$ found that the MEM subscale has a predominant role in discriminating between different types of dementia.

Influence of age on the scale performance was not verified. Considering that many studies show the influence of this factor, ${ }^{3,10,21}$ the study results may be explained by the age group of the sample, from 45 to 64 years. The influence of sex was not found either, similar to other studies. ${ }^{3,10,24}$ However, there were many women in the sample, which may have limited this analysis.

Regarding IQ, this variable was included following the recommendation of Mitrushina et al. found in a guide for normative studies on neuropsychological tests. ${ }^{25}$ It consists in a way to verify the influence of a present ability on DRS results, in contrast to formal education, which the participants had often completed years ago. In the overall comments about the DRS, Strauss, Spreen, and Sherman stated that the scale has a relatively good concurrent validity, with good correlation with the Wechsler scales (memory and intelligence). ${ }^{3}$ The present study showed a close relationship between the total score and the WASI, reinforcing this evidence. On the other hand, this study found a similar influence of education level and IQ on the results. Considering the time and cost of including an intelligence scale, researchers should think about its usefulness. Some authors suggest the investigation of other abilities instead of IQ such as reading habit. ${ }^{26}$

The present study has the limitation of selecting healthy people from a hospital unit among healthcare professionals and patients' caregivers. Multicenter studies should be further performed with a more representative sample of the Brazilian population.

Finally, the authors hope that normative data in the DRS presented in this study can support Brazilian clinicians and researchers in the great challenge posed by dementia diagnosis and follow-up.

\section{ACKNOWLEDGEMENTS}

Paulo Caramelli receives support from Conselho Nacional de Desenvolvimento Científico e Tecnológico (CNPq) - Brazil (scholarship of research productivity).

Authors' contributions. GAC: conceptualization, writing - original draft, and writing - review \& editing. PC: conceptualization, writing - original draft, and writing - review \& editing.

\section{REFERENCES}

1. Lezak MD, Howieson DB, Bigler ED, Tranel D. Neuropsychological assessment. 5. ed. New York: Oxford University Press; 2012.

2. Tsoi KKF, Chan JYC, Hirai HW, Wong SYS, Kwok TCY. Cognitive tests to detect dementia: a systematic review and meta-analysis. JAMA Intern Med. 2015;175(9):1450-8. https://doi.org/10.1001/jamainternmed.2015.2152

3. Strauss EH, Sherman EMS, Spreen O. A Compendium of Neuropsychological Tests - Administration, Norms and Commentary. 3. ed. New York: Oxford University Press; 2006.

4. Rascovsky K, Salmon DP, Hansen LA, Galasko D. Distinct cognitive profiles and rates of decline on the Mattis Dementia Rating Scale in autopsy-confirmed frontotemporal dementia and Alzheimer's disease. J Int Neuropsychol Soc. 2008;14(3):373-83. https://doi.org/10.1017/S135561770808051X

5. Lukatela K, Cohen RA, Kessler H, Jenkins MA, Moser DJ, Stone WF, et al. Dementia rating scale performance: a comparison of vascular and Alzheimer's dementia. J Clin Exp Neuropsychol (Neuropsychology, Dev Cogn Sect A). 2000;22(4):445-54. https://doi.org/10.1076/ 1380-3395(200008)22:4;1-0;FT445

6. Rosser AE, Hodges JR. The Dementia Rating Scale in Alzheimer's disease, Huntington's disease and progressive supranuclear palsy. J Neurol. 1994;241(9):531-6. https://doi.org/10.1007/BF00873515

7. Porto CS, Fichman HC, Caramelli P, Bahia VS, Nitrini R. Brazilian version of the Mattis Dementia Rating Scale: Diagnosis of mild dementia in Alzheimer' s Disease. Arq Neuro-Psiquiatr. 2003;61(2-B):339-45. https:// doi.org/10.1590/S0004-282X2003000300004
8. Porto CS, Caramelli P, Nitrini R. The influence of schooling on performance in the Mattis Dementia Rating Scale (DRS). Dement Neuropsychol. 2010;4(2):126-30. https://doi.org/10.1590/S198057642010DN40200009

9. Foss MP, Vale F de AC, Speciali JG. Influência da escolaridade na avaliação neuropsicológica de idosos: aplicação e análise dos resultados da Escala de Mattis para Avaliação de Demência (Mattis Dementia Rating Scale MDRS). Arq Neuro-Psiquiatr. 2005;63(1):119-26. https://doi.org/10.1590/ S0004-282X2005000100022

10. Foss MP, Carvalho VA, Machado TH, Reis GC, Tumas V, Caramelli P, et al. Mattis Dementia Rating Scale (DRS): Normative data for the Brazilian middle-age and elderly populations. Dement Neuropsychol. 2013;7(4):374-9. https://doi.org/10.1590/S1980-57642013DN74000004

11. Alzheimer's Association. Younger-earlier - onset Alzheimer's [Internet]. [accessed on Jul. 21, 2020]. Available at: https://www.alz.org/alzheimers-dementia/what-is-alzheimers/younger-early-onset

12. César KG. Estudo da prevalência de comprometimento cognitivo leve e demência na cidade de Tremembé, estado de São Paulo. 2014. 156f. Tese (Doutorado em Ciências). São Paulo: Universidade de São Paulo; 2014. https://doi.org/10.11606/T.5.2014.tde-15082014-161857

13. Carvalho GA, Caramelli P. Normative data for middle-aged Brazilians in verbal fluency (Animals and FAS), trail making test (TMT) and clock drawing test (CDT). Dement Neuropsychol. 2020;14(1):14-23. https:// doi.org/10.1590/1980-57642020dn14-010003 
14. Almeida OP. Mini Exame do Estado Mental e o diagnóstico de demência no Brasil. Arq Neuro-Psiquiatr. 1998;56(3B):605-12. https://doi.org/10.1590/ S0004-282X1998000400014

15. Brucki SMD, Nitrini $R$, Caramelli P, Bertolucci PHF, Okamoto IH. Sugestões para o uso do mini-exame do estado mental no Brasil. Arq Neuro-Psiquiatr. 2003;61(3 B):777-81. https://doi.org/10.1590/S0004282X2003000500014

16. Lecrubier Y, Weiller E, Hergueta T, Amorim P, Bonora LI, Lépine JP, et al [Internet]. M.I.N.I: Mini International Neuropsychiatric Interview - Brazilian version 5.0.0; 2002. p.26 [accessed on Mon. day, 20xx]. Available at: www.cosemssp.org.br/downloads/Cursos/Saude-Mental-DSM-07-03. pdf

17. Amorim P. Mini International Neuropsychiatric Interview (MINI): validação de entrevista breve para diagnóstico de transtornos mentais. Rev Bras Psiquiatr. 2000;22(3):106-15. https://doi.org/10.1590/S151644462000000300003

18. Wechsler D, Trentini CM, Yates DB, Heck VS. Escala Wechsler Abreviada de Inteligência - WASI: Manual. São Paulo: Casa do Psicólogo: 2014.

19. Siqueira AL, Tibúrcio JD. Estatística na área da saúde: conceitos, metodologia, aplicações e prática computacional. Belo Horizonte: COOPMED; 2011.

20. Strutt AM, Ayanegui IG, Scott BM, Mahoney ML, York MK, Montes LESM. Influence of socio-demographic characteristics on DRS-2 performance in spanish-speaking older adults. Arch Clin Neuropsychol. 2012;27(5):54556. https://doi.org/10.1093/arclin/acs049

21. Schmidt R, Freidl W, Fazekas F, Reinhart B, Grieshofer P, Koch M, et al. The Mattis Dementia Rating Scale: Normative data from 1,001 healthy volunteers. Neurology. 1994;44(5):964-6. https://doi.org/10.1212/ wnl.44.5.964

22. Dellatolas G, Braga LW, Souza LN, Filho GN, Queiroz E, Deloche G. Cognitive consequences of early phase of literacy. J Int Neuropsychol Soc. 2003;9(5):771-82. https://doi.org/10.1017/S1355617703950107

23. Smith GE, Ivnik RJ, Malec JF, Kokmen E, Tangalos E, Petersen RC. Psychometric properties of the mattis dementia rating scale. Assessmenet. 1994;1(2):123-31. https://doi.org/10.1177/1073191194001002002

24. Chan AS, Choi MK, Salmon DP. The effects of age, education, and gender on the Mattis Dementia Rating Scale performance of elderly Chinese and American individuals. J Gerontol B Psychol Sci Soc Sci. 2001;56(6):35663. https://doi.org/10.1093/geronb/56.6.P356

25. Mitrushina M, Boone KB, Razani J, D'Elia LF. Handbook of normative data for neuropsychological assessment [ebook]. 2. ed. New York: Oxford University Press; 2005.

26. Dotson VM, Kitner-Triolo MH, Evans MK, Zonderman AB. Effects of race and socioeconomic status on the relative influence of education and literacy on cognitive functioning. J Int Neuropsychol Soc. 2009;15(4):580-9. https://doi.org/10.1017/S135561770909082 